Volume 1 Nomor 2, Agustus 2016, halaman 113-122

\title{
ANALISIS MINAT BELAJAR DAN BAKAT TERHADAP HASIL BELAJAR MATEMATIKA SISWA
}

\author{
Ahmad Fadillah \\ Universitas Muhammadiyah Tangerang, fadiel_algebra@yahoo.co.id
}

\begin{abstract}
ABSTRAK
Tujuan dari penelitian ini adalah untuk mengetahui apakah terdapat pengaruh minat belajar dan bakat siswa terhadap hasil belajar siswa. Penelitian ini menggunakan metode kuantitatif survei dengan teknik korelasi. Penelitian ini dilakukan di SMPN 18 Tangerang, populasi penelitian adalah siswa kelas VII sebanyak 250 dan sampel penelitian sebanyak 153 siswa. Instrumen dalam penelitian ini tes dan kuesioner atau angket. Dari analisis korelasi ganda didapat $\mathrm{t}_{\text {hitung }}=23,208>\mathrm{t}_{\text {tabel }}=3,06$ untuk taraf signifikansi 5\% dan analisis regresi didapat $\mathrm{Y}=-101,501+2,96 \mathrm{x}_{1}+1,44 \mathrm{x}_{2} \quad$ yang artinya antara minat belajar, bakat siswa dan hasil belajar memiliki hubungan yang signifikan dan menunjukkan bahwa minat belajar dan bakat siswa berpengaruh terdapat hasil belajar matematika siswa.
\end{abstract}

Kata Kunci: Minat Belajar, Bakat, Hasil Belajar.

\section{ABSTRACT}

The purpose of this study was to determine whether there is influence students' interest in learning and talent of the student learning outcomes. This study uses a quantitative survey with correlation techniques. This research was conducted at SMPN 18 Tangerang, the study population was as many as 250 students of class VII and sample as many as 153 students. Instruments in this study tests and questionnaires or questionnaire. Of multiple correlation analysis obtained $t$ count $=23.208>t$ table $=3.06$ for the 5\% significance level and regression analysis obtained, which means the interest in learning, gifted students and learning outcomes have a significant relationship and shows that interest in learning and talent students are influential the results of students' mathematics learning. Keywords: Interest in Learning, Talent, Learning Outcomes.

\section{How to Cite: Fadillah, A. (2016). Analisis Minat Belajar dan Bakat Terhadap Hasil Belajar Matematika Siswa. Mathline: Jurnal Matematika dan Pendidikan Matematika, Vol.1, No.2, 113-122.}

\section{PENDAHULUAN}

Rendahnya hasil belajar matematika siswa disebabkan oleh beberapa faktor diantarannya adalah matematika merupakan salah satu pelajaran yang dianggap menjadi pelajaran yang sulit oleh peserta didik sehingga kurangnya minat belajar peserta didik terhadap pembelajaran matematika, banyak rumus-rumus yang harus dipelajari dan soal-soal 
yang sulit untuk dipahami, sehingga membuat minat dan bakat peserta didik tidak berkembang dalam mempelajari pelajaran matematika. Oleh karena itu minat dan bakat siswa dalam pembelajaran matematika harus dikembangkan, sehingga bakat merupakan potensi bawaan yang dimiliki manusia, sedangkan minat tercipta karena adanya ketertarikan kuat atas sesuatu. Kedua hal ini seringkali dikaitkan dengan faktor kecerdasan dan kesuksesan seseorang dalam belajar matematika memperoleh hasil yang maksimal.

Dalam menumbuhkan minat peserta didik dalam belajar terutama belajar matematika dapat dilakukan dengan berbagai cara. Misalnya saja dengan memberikan metode dan media pembelajaran kepada peserta didik agar minat peserta didik bertambah didalam belajar matematika meningkat dan peserta didik yang memiliki bakat dalam dirinya akan lebih mudah mencapai keberhasilan dalam kegiatan belajar.

Belajar merupakan salah satu faktor penting dari keseluruhan proses pendidikan karena belajar merupakan kegiatan pokok dalam proses tersebut. Namun dalam pembahasan belajar ini berarti berhasil tidaknya pencapaian tujuan pendidikan tergantung kepada bagaimana proses belajar yang dialami siswa (Susanto, 2013).

Menurut R.Gagne, belajar dapat didefinisikan sebagai suatu proses dimana suatu organisme berubah perilakunya sebagai akibat pengalaman. Belajar dan mengajar merupakan dua konsep yang tidak dapat dipisakan satu sama lain. Dua konsep ini menjadi terpadu dalam satu kegiatan dimana terjadi interaksi antara guru dan siswa, serta siswa pada saat belajar berlangsung. Bagi Gagne, belajar dimaknai sebagai suatu proses untuk memperoleh motivasi dalam pengetahuan, keterampilan, kebiasaan dan tingkah laku (Susanto, 2013).

Menurut Slameto belajar ialah suatu proses usaha yang dilakukan seseorang untuk memperoleh suatu perubahan tingkah laku yang baru secara keseluruhan, sebagai hasil pengalamannya sendiri dalam interaksi dengan lingkungan (Slameto, 2010).

Jadi, belajar adalah suatu proses usaha yang dilakukan seseorang untuk memperoleh suatu proses perubahan perilaku yang dilakukan oleh seseorang melalui pengalaman dan latihan yang telah dilakukannya sendiri secara keseluruhan sebagai hasil pengalaman dalam interaksi antara guru dan siswa.

Hasil belajar merupakan istilah yang digunakan untuk menunjukkan tingkat keberhasilan yang dicapai oleh seseorang setelah melakukan usaha tertentu. Dalam hal ini hasil belajar yang dicapai siswa dalam bidang studi tertentu setelah mengikuti belajar mengajar. Berdasarkan uraian tentang konsep belajar di atas, dapat dipahami tentang makna 
hasil belajar, yaitu perubahan-perubahan yang terjadi pada diri siswa, baik yang menyangkut aspek kognitif, afektif, dan psikomotor sebagai hasil dari kegiatan belajar (Susanto, 2013).

Menurut K. Brahim, hasil belajar dapat diartikan sebagai tingkat keberhasilan siswa dalam mempelajari materi pelajaran di sekolah yang dinyatakan dalam skor yang diperoleh dari hasil tes mengenal sejumlah materi pelajaran tertentu (Susanto, 2013).

Sedangkan menurut Gagne ada lima kategori hasil belajar, yakni: informasi verbal, kecakapan intelektul, strategi kognitif, sikap dan keterampilan. Sementara Benyamin Bloom mengungkapkan tiga tujuan pengajaran yang merupakan kemampuan seseorang yang harus dicapai dan merupakan hasil belajar yaitu: kognitif, afektif, dan psikomotorik. (Suprijoyo, 2009)

Menurut Bloom (Sudjana, 2009) ada enam tingkatan dalam kawasan kognitif yang berlaku juga untuk hasil belajar dalam kawasan ini yaitu: pengetahuan/Ingatan (knowledge), pemahaman (comprehension), penerapan aplikasi (application), analisis (analysis), sintesis , dan evaluasi (evaluation).

Sementara menurut Anderson dan Krathwohl (Siregar, 2010), melakukan revisi pada kawasan kognitif. Menurutnya terdapat dua kategori, yaitu dimensi proses kognitif dan dimensi pengetahuan. Pada dimensi proses kognitif, ada enam tujuan belajar, yaitu sebagai berikut: mengingat, mengerti, memakai, menganalisis, menilai, dan mencipta.

Hasil belajar siswa dapat diukur dengan menggunakan alat evaluasi yang biasanya disebut tes hasil belajar sedangkan pengertian matematika yang dikemukan oleh Suherman, berbagai pendapat muncul tentang pengertian matematika tersebut, dipandang dari pengetahuan dan pengalaman masing-masing yang berbeda. Matematika adalah ilmu tentang bilangan dan ruang, matematika adalah ilmu yang mempelajari hubungan pola bentuk, dan struktur, matematika adalah ilmu yang abstrak dan deduktif, matematika adalah aktivitas manusia (Suherman, 2010).

Menurut Ruseffendi matematika adalah simbol ilmu deduktif yang tidak menerima pembuktian secara ilmu tentang pola keteraturan. Sedangkan menurut Soedjadi (2000) matematika yaitu memiliki objek tujuan abstrak, bertumpu pada kesepakatan, dan pola pikir yang deduktif.

Jadi, dari berbagai ahli di atas pengertian tentang hasil belajar matematika, maka dapat disimpulkan bahwa hasil belajar matematika adalah hasil yang dicapai oleh siswa setelah 
mengikuti proses belajar mengajar dalam kurang waktu tertentu akan diperlihatkan melalui skor yang diperoleh tes hasil belajar matematika.

Faktor-faktor yang mempengaruhi hasil belajar menurut Wasliman (Susanto, 2013) hasil belajar yang dicapai siswa, yang mempengaruhi, baik faktor internal maupun eksternal. Secara perincian uraian mengenai faktor internal dan eksternal sebagai berikut: faktor internal terdiri dari: Kecerdasan, minat dan perhatian, motivasi belajar, ketekunan, sikap, kebiasaan belajar, serta kondisi fisik dan kesehatan. Sedangkan faktor ekternal terdiri dari: keluarga, sekolah, dan masyarakat.

Menurut Sukardi, minat dapat diartikan sebagai suatu kesukaan, kegemaran atau kesenangan bahwa minat timbul tidak secara tiba-tiba atau spontan, melainkan timbul akibat dari partisipasi, pengalaman kebiasaan pada waktu belajar. (Susanto, 2013).

Menurut Slameto (2010), minat adalah suatu rasa lebih suka dan rasa terikatan pada suatu hal atau aktivitas, tanpa ada yang menyuru. Hal ini menujukan bahwa minat dapat menjadi motivasi yang mendorong seorang untuk melakukan apa yang diinginkan. Minat mempunyai peranan yang sangat penting dalam perkembangan belajar siswa. Siswa yang menaruh minat pada suatu bidang tertentu, maka akan berusaha lebih keras dalam menekunin bidang tersebut dibanding siswa yang tidak menaruh minat. Menurut Slameto (2010), minat adalah kecenderungan yang tetap untuk memperhatikan dan mengenang beberapa kegiatan. Kegiatan yang diminta siswa, diperhatikan terus-menerus yang disertai rasa senang dan diperoleh rasa kepuasan. Lebih lanjut dijelaskan minat adalah suatu rasa suka dan ketertarikan pada suatu hal atau aktivitas, tanpa ada yang menyuruh.

Menurut Crow and Crow bahwa minat berhubungan dengan gaya yang mendorong seseorang yang menghadapi atau berurusan dengan orang, benda, kegiatan, pengalaman yang dirangsang oleh kegiatan itu sendiri (Djaali, 2008).

Menurut Reber, minat tidak termasuk istilah, populer dalam psikologi karena kebergantungannya yang banyak pada faktor-faktor internal lainnya (Muhibbinsyah, 2010).

Berdasaarkan pendapat beberapa para ahli maka dapat disimpulkan bahwa minat belajar adalah merupakan suatu kesukaan, kegiatan atau aktivitas akan mendukung kelancaran kegiatan belajar. Minat dapat timbul apabila ada perhatian, dengan demikian minat juga dapat dikatakan sebagai sebab serta akibat dari perhatian dalam kaitan belajar. Faktor-faktor yang mempengaruhi minat belajar yaitu: motivasi, sikap terhadap guru dan pelajaran, keluarga, fasilitas sekolah, dan teman pergaulan. Dengan demikian minat belajar 
dipengaruhi oleh faktor-faktor yang saling berhubungan erat dan tidak dapat berdiri sendiri dalam memberikan pengaruh pada minat belajar.

Menurut Elizabeth Hurlock, ada tujuh ciri minat, yang masing-masing dalam hal ini tidak dibedakan antara ciri minat secara spontan maupun terpola sebagaimana yang dikemukakan oleh Gagne di atas sebagai berikut (Susanto, 2013):

1. Minat tumbuh bersamaan dengan perkembangan fisik dan mental. Minat di semua bidang berubah selama terjadi perubahan fisik dan mental, misalnya perubahan minat dalam hubungannya dengan perubahan usia.

2. Minat tergantung pada kegiatan belajar, misalnya kesiapan belajar merupakan salah satu penyebab meningkatnya minat seseorang.

3. Minat tergantung pada kesempatan belajar, misalnya kesempatan belajar merupakan fakot yang sangat berharga, sebab tidak semua orang dapat menikmatinya.

4. Perkembangan minat mungkin terbatas. Misalnya keterbatasan ini mungkin dikarenakan keadaan fisik yang tidak memungkinkan

5. Minat dipengaruhi budaya, misalnya budaya sangat memengaruhi sebab jika budaya sudah mulai luntur mungkin minat juga ikut luntur.

6. Minat berbobot emosional, misalnya minat berhubungan dengan perasaan senang yang akhirnya dapat diminatinya.

7. Minat berbobot egosentris, misalnya jika seseorang senang terdapat sesuatu, maka akan timbul hasrat untuk memilikinya.

Menurut Chaplin, yang dimaksud dengan bakat adalah kemampuan pontesial yang dimiliki seseorang untuk mencapai keberhasilan masa yang akan datang, sehubungan dengan hal tersebut, maka bakat akan dapat memengaruhi tinggi rendahnya prestasi belajar. (Susanto, 2013)

Menurut Utami Munandar, bakat merupakan potensi yang masih memerlukan ikhtiar pengembangan dan pelatihan secara serius dan sistematis agar dapat terwujud (Ali, 2005). Menurut Asrori (2009) bakat adalah kemampuan alamiah untuk memperoleh pengetahuan dan terampilan, baik yang bersifat umum dan khusus. Bakat seseorang berkemungkinan untuk mencapai prestasi dalam bidang tertentu. Tetapi untuk mewujudkan bakat ke dalam suatu prestasi diperlukan latihan, pengetahuan, pengalaman dan motivasi. 
Menurut Reber, dengan demikian, sebetulnya setiap orang pasti memiliki bakat dalam arti berpotensi untuk mencapai prestasi sampai ke tingkat tertentu sesuai dengan kepasitas masing-masing (Muhibbinsyah, 2010).

Menurut Greenes (Munandar, 1999), fleksibilitas dalam mengolah data, kemampuan luar biasa untuk menyusun data, ketangkasan mental, penafsiran yang orisinil, kemampuan luar biasa untuk generalisasi. Greenes menambahkan bahwa siswa berbakat matematika lebih menyukai komunikasi lisan daripada tulisan. Saran bagi guru dalam merencanakan model pembelajaran bagi siswa yang berbakat matematika: mendorong pertimbangan dan pemikiran mandiri, mendorong siswa untuk menggunakan berbagai metode untuk memecahkan masalah yang sama, mendorong siswa untuk melakukan pengecekan, memberikan masalah yang menantang dan luar biasa kecakapan potensial seseorang hanya dapat dideteksi dengan mengidentifikasi indicator-indikatornya. Jika kita perhatikan penjelasan tentang aspek-aspek inteligensi dari teori-teori inteligensi di atas, maka pada dasarnya indikator bakat akan mengerucut ke dalam tiga ciri yaitu: kecepatan (waktu yang singkat), ketepatan (hasil yang sesuai dengan yang diharapkan), dan kemudahan (tanpa menghadapi hambatan dan kesulitan yang berati) dalam bertindak.

Dari beberapa para ahli maka dapat disimpulkan bakat adalah merupakan suatu mencapai prestasi belajar memiliki dalam arti berpotensi untuk mencapai prestasi belajar sampai ke tingkat tertentu.

Bakat siswa dapat dipengaruhi 2 faktor yaitu: faktor Internal (minat, motivasi, keberanian atau beresiko, keuletan dalam menghadapi tantangan, dan egigihan dalam mengatasi kesulitan yang timbul). Sedangkan faktor eksternal (kesempatan maksimal untuk mengembangkan diri, sarana dan prasarana, ukungan dan dorongan orang tua dan keluarga, dan lingkungan tempat tinggal).

Dari uraian di atas dapat disimpulkan bahwa bakat siswa masih bersifat potensial dan masih dipengaruhi faktor internal dan faktor eksternal, sehingga dalam perwujudnya masih sangat memerlukan pembinaan sistematis dan maksimal.

Menurut Asrori (2009), ada sejumlah langkah yang perlu dilakukan untuk mengembangkan bakat individu yaitu: 1) Mengembangkan situasi dan kondisi yang memberikan kesempatan bagi anak-anak untuk mengembangkan bakat dengan mengusahakan yang baik. 2) Berupaya motif berprestasi yang tinggi di kalangan anak baik dalam lingkungan keluarga, sekolah, maupun masyarakat. 3) Meningkatkan kegigihan dan 
daya juang pada diri anak dalam menghadapi berbagai tantangan dan kesulitan. 4) Mengembangkan program pendidikan berdiferensi di sekolah dengan kurikulum berdiferensiasi pula guna memberikan pelayanan secara lebih efektif kepada anak yang memiliki bakat.

Dalam menumbuhkan minat peserta didik dalam belajar terutama belajar matematika dapat dilakukan dengan berbagai cara. Misalnya saja dengan memberikan metode pembelajaran dan media pembelajaran kepada peserta didik agar hasil belajar peserta didik dalam belajar matematika meningkat dan peserta didik yang memiliki minat dan bakat dalam dirinya akan lebih mudah mencapai keberhasilan dalam kegiatan belajar.

Dari keterangan di atas, dapat dijelaskan bahwa siswa yang memiliki hasil belajar yang baik dengan peserta didik yang tidak memiliki hasil belajar yang baik akan terdapat perbedaan. Perbedaan tersebut tampak jelas jika dilihat dari minat dan bakat peserta didik tersebut. Peserta didik yang memiliki minat dan bakat maka ia akan terus tekun ketika belajar sedangkan peserta didik yang tidak memiliki minat walau pun ia mau untuk belajar akan tetapi ia tidak terus untuk tekun dalam belajar. Sehingga minat dan bakat siswa mengakibatkan motivasi belajar matematika. Dengan demikian peserta didik juga dapat memahami matematikan dengan ketekunan dan ketelitian yang tinggi. Hasil belajar matematika diharapkan lebih meningkat.

Sehubungan dengan masalah tersebut di atas maka peneliti ingin mengkajinya dalam "Analisis Minat Belajar dan Bakat Terhadap Hasil Belajar Matematika Siswa" dengan perumusan masalah apakah terdapat pengaruh minat dan bakat siswa terhadap hasil belajar matematika siswa?.

\section{METODE PENELITIAN}

Penelitian ini dilakukan di SMPN 18 Tangerang. Dalam penelitian ini peneliti menggunakan metode penelitian survei. Populasi dalam penelitian ini adalah siswa kelas VII SMPN 18 Tangerang yang berjumlah 250 siswa. Sampel dalam penelitian ini adalah kelas VII sebanyak 153 jumlah tersebut di dapat dari rumus Slovin (Amirin, 2011)

Instrumen yang digunakan adalah tes pilihan ganda berjumlah 10 soal untuk mentukan hasil belajar dan kuesioner atau angket digunakan untuk mentukan minat dan bakat siswa. Sebelum instrumen digunakan terlebih dahulu dilakuan uji validitas dan reliabilitas. 
Dalam penelitian ini dengan dua variabel independen $\mathrm{X}_{1}$ (minat belajar) dan $\mathrm{X}_{2}$ (bakat siswa) dan satu variabel dependen $\mathrm{Y}$ (hasil belajar matematika). Mencari hubungan $\mathrm{X}_{1}$ dengan $\mathrm{Y}$ dan $\mathrm{X}_{2}$ dengan $\mathrm{Y}$, menggunakan teknik regresi sederhana. Mencari hubungan $\mathrm{X}_{1}$ dengan $\mathrm{X}_{2}$ secara bersama-sama terhadap Y menggunakan regresi ganda.

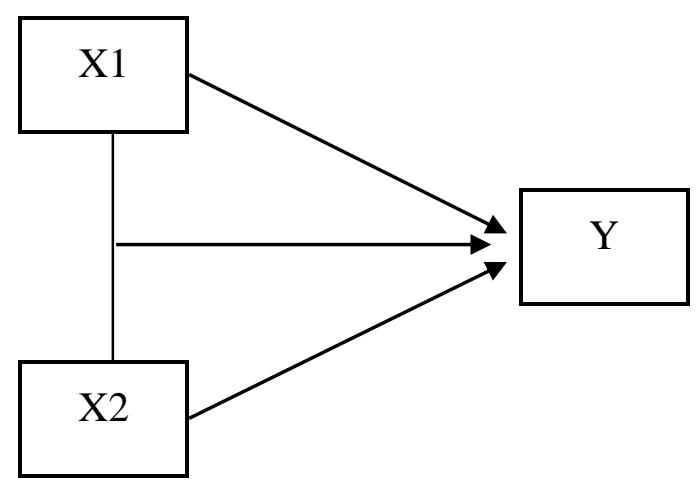

Gambar 1. Konstelasi Penelitian

\section{HASIL DAN PEMBAHASAN}

Berdasarkan pengujian yang dilakukan, diperoleh:

1. Uji linieritas regresi: Berdasarkan hasil analisis perhitungan menunjukan bahwa $X_{1}$ dan $X_{2}$ atas $Y$ berasal linier. Diperoleh $F_{\text {hitung }}=0,043$ dan $F_{\text {tabel }}$ 3,91 pada taraf signifikan $\alpha=0,05$, karena $\mathrm{F}_{\text {hitung }}<\mathrm{F}_{\text {tabel }}$ maka tolak $\mathrm{H}_{1}$ terima $\mathrm{H}_{0}$. Dengan demikian garis regresi $\mathrm{Y}$ atas $\mathrm{X}_{1}$ dan $\mathrm{X}_{2}$ adalah linier.

2. Uji signifikansi persamaan regresi ganda $Y$ atas $X_{1}$ dan $X_{2}$ : diperoleh $F_{h i t u n g}=23,208$ dan $\mathrm{F}_{\text {tabel }}=3,91$, karena $\mathrm{F}_{\text {hitung }}>\mathrm{F}_{\text {tabel }}$ maka $\mathrm{H}_{\mathrm{o}}$ ditolak dan maka $\mathrm{H}_{1}$ diterima. Dengan demikian korelasi antara $\mathrm{X}_{1}$ dan $\mathrm{X}_{2}$ dengan $\mathrm{Y}$ adalah positif dan signifikan.

3. Uji signifikansi koefisien korelasi: diperoleh $F_{\text {hitung }}=23,16$ dan $F_{\text {tabel }}=3,91$, karena $F_{\text {hitung }}$ $>\mathrm{F}_{\text {tabel }}$ maka $\mathrm{H}_{\mathrm{o}}$ ditolak dan maka $\mathrm{H}_{1}$ diterima. Dengan demikian korelasi antara $\mathrm{X}_{1}$ dan $\mathrm{X}_{2}$ dengan $\mathrm{Y}$ adalah positif dan signifikan.

4. Korelasi parsial dan ganda dan uji signifikansi koefisien korelasi (Uji tingkat kerataan dengan Uji t): diperoleh $F_{\text {hitung }}=0,899$ dan $F_{\text {tabel }}=1,645$, karena $F_{\text {hitung }}<F_{\text {tabel }}$ maka $\mathrm{H}_{0}$ ditolak dan maka $\mathrm{H}_{1}$ terima. Dengan demikian koefesien korelasi $\mathrm{X}_{1}$ atas $\mathrm{Y}$ adalah tidak signifikan. Artinya secara parsial tidak ada pengaruh antara minat belajar dengan hasil belajar matematika mengontrol bakat siswa. 
5. Perhitungan uji signifikansi koefesien korelasi di peroleh $F_{\text {hitung }}=1,84$ dan $F_{\text {tabel }}=1,64$, karena $\mathrm{F}_{\text {hitung }}>\mathrm{F}_{\text {tabel }}$ maka $\mathrm{H}_{0}$ ditolak dan maka $\mathrm{H}_{1}$ terima. Dengan demikian koefesien korelasi $\mathrm{X}_{2}$ atas $\mathrm{Y}$ adalah signifikan. Artinya secara parsial berpengaruh antara bakat siswa dengan hasil belajar matematika mengontrol minat belajar.

Tabel 1. Signifikansi Koefesien Korelasi Regresi Antara $X_{1}$ dan $Y$

\begin{tabular}{cccc}
\hline \multicolumn{2}{c}{ Hasil perhitungan } & Keterangan & Kesimpulan \\
\hline $\mathrm{T}_{\text {hitung }}=0,899$ & $\mathrm{~T}_{\text {tabel }}=1,645$ & $\mathrm{~T}_{\text {hitung }}<\mathrm{T}_{\text {tabel }}$ & Tidak Signifikan \\
\hline
\end{tabular}

Tabel 2. Signifikansi Koefesien Korelasi Regresi Antara $X_{2}$ dan $Y$

\begin{tabular}{cccc}
\hline \multicolumn{2}{c}{ Hasil perhitungan } & Keterangan & Kesimpulan \\
\hline $\mathrm{T}_{\text {hitung }}=1,84$ & $\mathrm{~T}_{\text {tabel }}=1,64$ & $\mathrm{~T}_{\text {hitung }}>\mathrm{T}_{\text {tabel }}$ & Signifikan \\
\hline
\end{tabular}

Dari analisis korelasi ganda terungkap bahwa hipotesis terbukti hal ini ditunjukan dari $\mathrm{t}_{\text {hitung }}=23,208>\mathrm{t}_{\text {tabel }}=3,06$ yang artinya dikatakan bahwa ketiga variabel ini mempunyai hubungan yang signifikan. Hal ini berarti hipotesis yang dibuat memang benar adanya bahwa hasil belajar matematika dapat dipengaruhi oleh minat belajar dan bakat sisawa. Selain itu ketiga variabel juga mempunyai hubungan masing masing yang saling mempengaruhi.

Dari persamaan $\mathrm{Y}=\mathrm{a}+\mathrm{bx}_{1}=-93651,3+225,0755 \mathrm{bx}_{1}$ hal ini menunjukkan bahwa perubahan minat belajar memberikan pengaruh pada perubahan hasil belajar matematika siswa secara signifikan. Dari persamaan $\mathrm{Y}=\mathrm{a}+\mathrm{bx}_{2}=-101,646+300754,02 \mathrm{x}_{2}$ hal ini menunjukkan bahwa perubahan bakat siswa memberikan pengaruh pada perubahan hasil belajar matematika siswa secara signifikan. Dari persamaan $Y=-101,501+2,96 x_{1}+1,446 x_{2}$ hal ini menunjukkan bahwa minat belajar dan bakat siswa berpengaruh terdapat hasil belajar matematika siswa.

\section{KESIMPULAN}

Berdasarkan hasil analisis dan kajian teori di aatas, maka peneliti memberikan kesimpulan yaitu:

1. Terdapat tidak berpengaruh antara minat belajar dengan hasil belajar matematika. diperoleh $\mathrm{F}_{\text {hitung }}=0,899916$ sedangkan $\mathrm{F}_{\text {tabel }}=1,645$.

2. Diperoleh $\mathrm{Y}=\mathrm{a}+\mathrm{bx}_{1}=-93651,3+225,0755 \mathrm{bx}_{1}$ hal ini menunjukkan bahwa perubahan minat belajar memberikan pengaruh pada perubahan hasil belajar matematika siswa secara signifikan. 
3. Diperoleh $\mathrm{Y}=\mathrm{a}+\mathrm{bx}_{2}=-10164640+300754,02 \mathrm{x}_{2}$ hal ini menunjukkan bahwa perubahan bakat siswa memberikan pengaruh pada perubahan hasil belajar matematika siswa secara signifikan.

4. Diperoleh $\mathrm{Y}=-101,5011+2,964 \mathrm{x}_{1}+1,44 \mathrm{x}_{2}$ hal ini menunjukkan bahwa minat belajar dan bakat siswa berpengaruh terdapat hasil belajar matematika siswa.

Adapun saran dari peneliti adalah agar para pendidik lebih memeperhatikan lagi minat dan bakat siswa, karena mereka memilki minat dan bakat yang unik serta berbeda satu dengan yang lainnya sehingga minat dan bakat mereka dapat dioptimalkan secara maksimal. penelitian ini adalah analisis minat belajar dan bakat siswa dalam hasil belajar matematika. Dalam hal ini juga terdapat upaya-upaya lain yang perlu diperbaiki dalam meningkatkan hasil belajar matematika melaui minat belajar dan bakat siswa dengan berbagai persiapan yang matang. Diantaranya guru harus memperhatikan peserta didik kembali yang akan diajarkan dengan jangka waktu yang lebih lama sehingga peserta didik dapat memahami materi dan lebih teliti dalam mengerjakan soal-soal.

\section{DAFTAR PUSTAKA}

Ali, M. (2005). Teori-Teori Psikologi. Yogyakarta: Ar-Ruzz Media.

Amirin, T. M. (2011). Populasi dan Sampel Penelitian 4: Ukuran Sampel Rumus Slovin. 24 Maret 2015. tatangmanguny.wordpress.com.

Asrori, M. (2009). Psikologi Pembelajaran. Bandung: Bumi Rancaekek Kencana.

Djaali. (2008). Psikologi Pendidikan. Jakarta: PT Bumi Aksara

Muhibbinsyah (2010). Psikologi Pendidikan. Bandung: PT Remaja Rosdakarya.

Siregar, E. (2010). Teori Belajar Dan Pembelajaran. Bogor: Ghalia Indonesia

Slameto. (2010). Belajar dan Faktor-Faktor yang Pengaruhi. Jakarta: PT. Rineka Cipta.

Soedjadi. (2000). Kiat Pendidikan Matematika di Indonesia. Jakarta: Direktorat Jendral Pendidikan Tinggi Departemen Pendidikan Nasional

Sudjana, N. (2009). Penilaian Hasil Proses Belajar Mengajar. Bandung: PT. Remaja Rosdakarya.

Suherman. (2010). Metode Penelitian Pendidikan. Bandung: UPI Press

Suprijoyo, A. (2009). Cooperative Learning. Yogyakarta: PT. Celeban Timur.

Susanto, A. (2013). Teori Belajar dan Pembelajaran di Sekolah Dasar. Jakarta: PT Kharisma Putra Utama.

Utami, Munandar. (1999). Pengembangan Kreativitas Anak Berbakat. Jakarta: Rineka Cipta. 